\title{
Community Participation, Sustainable Development and Slum Settlements in Jakarta
}

\author{
Yoka Pramadi ${ }^{1}$, Praditya Mer Hananto ${ }^{2}$, Rusydan Fathy ${ }^{3}$, Dicky Rachmawan ${ }^{4}$, Hidayatullah \\ Rabbani $^{5}$ \\ \{yoka.pramadi@lipi.go.id ${ }^{1}$, battle_signal@yahoo.com² ${ }^{2}$ rusydanfathy@gmail.com ${ }^{3}$, \\ dicky.rachmawan1992@gmail.com ${ }^{4}$, hidayatullahrabbani@gmail.com $\left.{ }^{5}\right\}$
}

Indonesian Institute of Science, Jakarta ${ }^{1,2,3,4,5}$

\begin{abstract}
One of the SDG (Sustainable Development Goals) programs being implemented by the Indonesia government is "Sustainable Cities and Communities: Make cities and human settlements inclusive, safe, resilient and sustainable". Why it matters? The United Nations (UN) explicate that the cost of poorly planned urbanization can be seen in some of the huge slums, tangled traffic, greenhouse gas emissions and sprawling suburbs all over the world. Slums are a drag on GDP, and lower life expectancy. By choosing to act sustainably we choose to build cities where all citizens live a decent quality of life, and form a part of the city's productive dynamic, creating shared prosperity and social stability without harming the environment. Jakarta as Indonesia's capital city currently has many slums. But not all settlements are always in a slum condition. In our findings, basically there are 3 kinds of transformation of the slum settlements, namely: (1) Zero to Hero: settlements that used to be slum and then transformed into good settlement, being tough and staying sustainable even becoming an instagramable; (2) Zero to Ash: settlements that are slum and end remain up displaced and disappear; (3) Hero to Zero: settlements that are not slum then become slums. This transition condition perfectly reverses the resident's ability, government policy, as well as the combination in handling it. This study uses the point of view of criminogenic behavior and crisis communication in dissecting existing phenomena.
\end{abstract}

Keywords: community participation; sustainable development; slum settlement; inclusive; empowerment.

\section{Introduction}

One of the SDG (Sustainable Development Goals) programs being implemented by the Indonesia government is "Sustainable Cities and Communities: Make cities and human settlements inclusive, safe, resilient and sustainable". Why it matters? The United Nations (UN) explicate that The cost of poorly planned urbanization can be seen in some of the huge slums, tangled traffic, greenhouse gas emissions and sprawling suburbs all over the world. Slums are a drag on GDP, and lower life expectancy. By choosing to act sustainably we choose to build cities where all citizens live a decent quality of life, and form a part of the city's productive dynamic, creating shared prosperity and social stability without harming the environment. Jakarta as Indonesia's capital city currently has many slums.

The Community Action Plan (CAP) is a program of the Governor of DKI Jakarta, Anies Baswedan, to organize slums in Jakarta. CAP is the first stage of structuring planning. 
Innovation of government development programs, both central and regional, always alternates from one leader to another. The existing bureaucracy is conventional and unable to anticipate changes. Forms of communication patterns of government institutions that occur at this time are top-down.

Individual communication patterns in socializing, interacting well between individuals, organizations and between communities and government are greatly influenced by cultural characteristics. This becomes increasingly apparent when we communicate with individuals from different cultures or groups of society. We can say bureaucrat with its dominant class culture and society with various obligations to submit to the power of the state. The internal obstacle in our current government bureaucracy is paternalistic communication patterns. External barriers are static, pessimistic and skeptical attitudes towards development efforts. The communication pattern that must be developed in the CAP program is participatory communication. This pattern can be used as an innovation in development with a bottom-up approach. Participatory communication provides a space for people to exchange information and knowledge. The application of participatory communication is carried out through dialogical principles.

This research was conducted in several sample locations that indicated slums and had evicted. From several slum areas, we collected data from Kampung Pulo, Jatinegara, East Jakarta and Kampung Akuarium, Penjaringan, North Jakarta. Kampung Akuarium in North Jakarta is one example of turning a slum (zero) into a good area (hero). During the era of governor Basuki Tjahaja Purnama, the village was evicted, which would later be rebuilt by the next governor, Anies Baswedan, in the Community Action Plan (CAP) program. Slum settlements are densely populated residential areas in an urban area, with poor housing conditions and the residents are lower class citizens.

While Kampung Pulo, Jatinegara District, East Jakarta is a densely populated area on the banks of the Ciliwung River. These problems are social problems, such as criminogenic problems. One effort that can be done is the Prevention of Crime Through Environmental Design (CPTED). Kampung Akuarium has a master plan for development in the CAP program and Pulo village is expected to have the CPTED element.

The terms slum settlements and slums housing are set out in Law Number 1 of 2011 (Undang-undang No.1/2011), Article 1 Number 13, concerning Housing and Settlement Areas. Slum settlements are settlements that are not suitable for habitation because of building irregularities, high levels of building density, and the quality of buildings and facilities and infrastructure that do not meet the requirements. Meanwhile, slum housing is housing that has decreased the quality of its function as a residence. Slums are often seen as an area that is synonymous with apathetic, overpopulated, inadequate, inadequate, poor, dilapidated, dangerous, insecure, dirty, below standard, unhealthy and many other negative stigma [1].

The United Nations Human Settlements Programme (UN-HABITAT) defines a slum area as a household that unable to provide one of basic living such as: 1) Durable house that able to protect against extreme climate condition.2) Sufficient living space, which means no more than three people sharing the same room. Of course, the room refer to building code. 3) Easy access to water in sufficient amounts at an affordable price. 3) Access to adequate sanitation in the form of a private or public toilet shared by a reasonable number of people. 4) Security of tenure that prevents forced evictions.

Of course, since it said "area" means that there are many households in that condition together and dense in the same urban area. The "slum" term tend to pejorative both in social and physical connotations which is applied by outsiders, often to justify public intervention such as 
slum clearance. A slum area usually habitated by marginalized people: those who have very low income, underdeveloped and low educated.

There is a kind of problem which tends to generate in slum area: an unmeet standard human basic living. If we go by Maslow's Hierarchy of Needs, there will be "basic needs" that every human had to get: psychology needs (food, water, warmth, rest) and safety needs (security, safety). As the UN-HABITAT state earlier, its called slum area because of its inability to provide some basic living which is it's same that Maslow's theory. Condition that unable to fulfill basic need not only make them vulnerable to multi-impact of inhabitant area such as disease and malnutrition, but also emerge conflict and justification to get its basic need. Hence encourage them to do anything to obtain it, such as resort to crime action.

\section{Condition to Emerge Criminal Behaviour}

Sutherland \& Cressey (1960) argue about what condition causing criminal behavior. For example, negroes, urban-dwellers, and young adults tend to have comparatives high crime rates [25]. Research studies have shown that criminal behavior is related to social and personal pathologies, such as poverty, bad housing, slums area, inadequate and demoralized families, emotional, and other traits nor condition. Yet research studies also have shown that any person with that kind pathologies didn't commit crime, and those who in upper social economy class tend to violate the law although they didn't have bad housing nor live in slums area. Of course, there is a different crime, which means violating the law, that doable by the poor and the not poor. It's mean that just because someone has that kind of social and pathological trait, it will not make them a criminal because there is still another factor to make crime occur.

Let us illustrate a story. Several years ago, in some slum area two boys engaged in a minor theft, they flee when they were discovered by the owner. The first boy, thanks to his athletic ability able to escape by jump across the fence, and later became a priest. The second boy who has a bigger body yet slower get caught, send to penitentiary, and later become a drug dealer. So, what's make the second boy became criminal? That's not because he commits crime by "stealing" (since he is still a boy) nor because run slower hence get caught and spend time in penitentiary, but because he associated with some drug dealer in penitentiary while the first boy associated some priest in his living area. That's the experience factor that makes the second boy became a criminal.

What is the connection between association and slum area in this part? Because slum area composed by crowded dense house one to another. That kind of environment tends to make easier for someone to associate with another. So, if by some unfortunate event some kid is associated with an active criminal, that kid will learn how to do criminal activity. And when his basic need is unmet, there is a chance that he will use his criminal knowledge to fulfill it because his condition makes him able to do it: commit a crime. Hence the result, that kid became another criminal.

Thanks to his criminal ability, the "kid", who now is a full grown-up adult, able to fulfill his basic need. Now he not just a one criminal person, but also a part of some crime syndicate. He still lives in his slum area, somehow never get caught, but have a better life than his honest living neighborhood. His better lifestyle with an "easy" job will attract the younger ones. Those younger generation will see him as someone who doing "easy work", yet have generous income than others. So, the younger will associated with him and his crew, transfer their "crime culture", and another person with criminal knowledge is born, waiting for a perfect chance to use his ability. That's the perspective stigma from outsider about slum area, a place where a criminal "born". 
Another way to prevent the birth of either crime or criminal, is through some design. As the name implied, Crime Prevention Through Environmental Design (CPTED) is a theory that basically focused on crime prevention. Its theory composed by law enforcement, architect and even involving resident in community area to create a safety situation that preventing crime. Basically the theory have four point to highlight: control access, survelliance, territorially and maintenance. The CPTED theory itself also using another theory, such as Felson \& Cohen's Routine Activity theory to Glasl's Conflict Escalation. The essence of that theory is that crime is occur when there is an encounter between two party, like criminal candidate meet victim candidate, plus a kind of $\mathrm{X}$ factor that trigger the crime situation, like the absence of guardian, offender capability, victim vulnerability, even some "history" between them. So to prevent the crime we need to "manipulate" the environtment such as add a CCTV at certain point, resident patrolling, even merging or separate to isolate some area.

\section{Methods}

Qualitative research method is used in this research to understand and examine about factors which relate with the transformation of slum area especially in Jakarta. We use two steps to find the factors and understand about slum transformation as flow in our research. Firstly, we use literature study that tell us about urbanization, social exclusion and stigma of slum settlement. In addition, historical view is used to descript about "Hero to Zero" transformation relate with slum are in Jakarta from 1960's and policy dynamic which had taken from previous governor in general description. Secondly, field research, consist of field observation and interview, is used for taking out primary data collection about "Zero to Ash" and "Zero to Heroes" transformation. Field observation and interview are used to collect not only physical, but also social aspect.

To understand how the process of transformation we interview several residents and community leaders that still exist near the site of the slum areas "revitalization". As a success story of transformation of slum area which we called "Zero to Hero", we use Kampung Akuarium as research site. Contradicting with Kampung Akuarium's Story, we use Kampung Pulo as research site as "Zero to Ash" case. After we explain about transformation categories of slum area in the end of this paper, then we demonstrate five stages activity to empowerment slum area community.

\section{Results and Discussions}

\subsection{Urbanization, Social Exclusion and Stigma of Slum Settlement}

Slum areas appear in almost every country in the world which around one billion people live there [13]. In Indonesia context, slum areas had reported exist since the colonial era in the

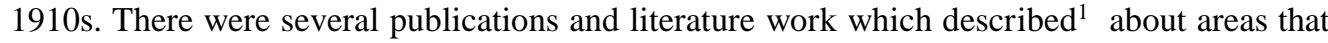
had poor amenities from health until sanitation that lived by poor people who came from outer Jakarta region especially from rural areas.

\footnotetext{
${ }^{1}$ Westerveld in 1914, Hendrik Freek Tillema in 1920, and Ajip Rosidi (Famous Sundanese Writer) in 1950s (Hanggoro, 2019).
} 
Then, Slum areas have continued and growth in Jakarta. Although Jakarta's Government have tried to reduce slum area with demolition and relocation settlement since 1960s, because in that time $60 \%$ Jakarta's people lived in crowded slum areas stated by Ali Sadikin (as Jakarta's Governor).

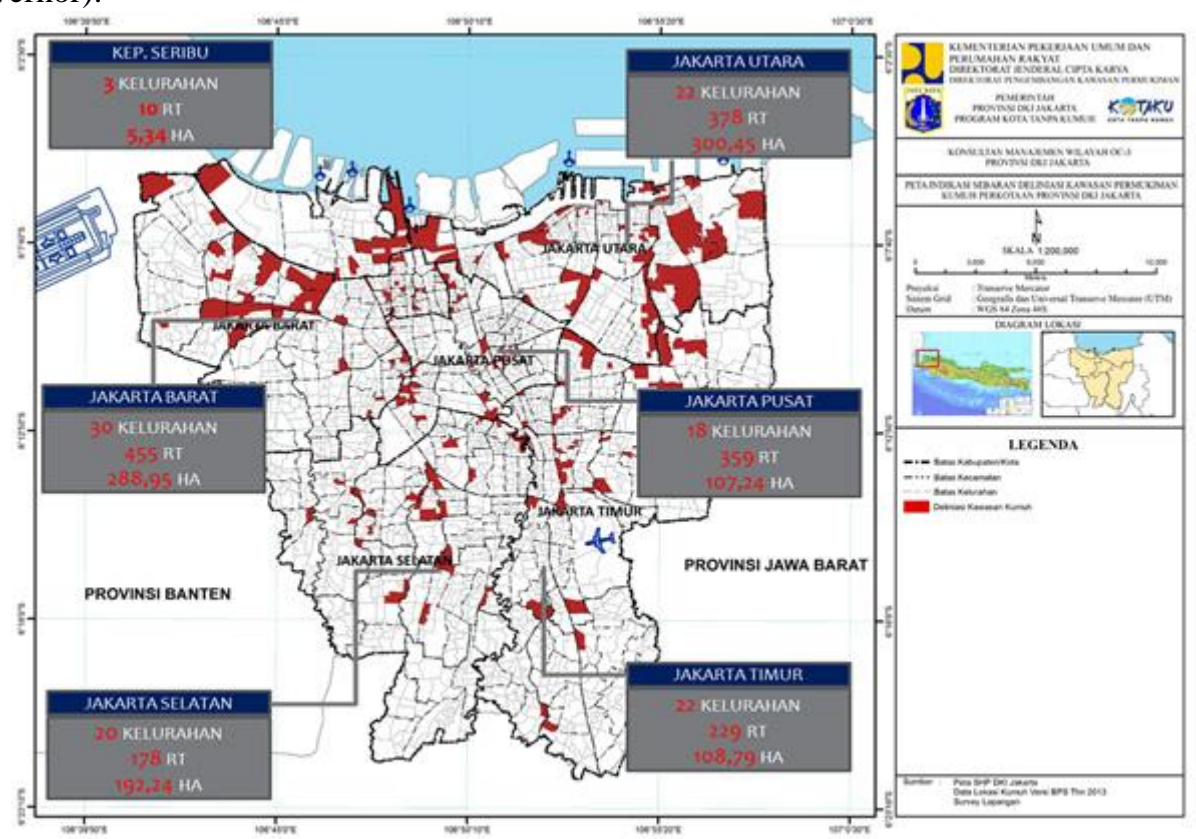

Fig. 1. Maps of Slum Area in Jakarta.

In recent times in Jakarta, around 118 from 267 villages (49\%) have slum areas ([12]; [29]). These areas spread out in six districts which consists of $39 \%$ in North Jakarta, $28 \%$ in West Jakarta, $19 \%$ in South Jakarta, 12\% in East Jakarta, 11\% in Central Jakarta and 1\% in Kepulauan Seribu [29].

Poverty and urbanization are the main factors of slum areas growth such big city as Jakarta ([13]; [3]; [16]). From this point of view, so we try to examine the urbanization in Jakarta related to the growth of slum areas. The importance of this study relates with goals No.11 from SDGs' about build inclusive, safe, strong, and sustainable city and settlement [5], further in goal No.11.1 which stated to ensure fulfilled accessibility of basic need, safety, affordable housing for everyone and improve slum areas [7].

Before we see urbanization in Jakarta, lets we see about Indonesia's urbanization in general. Prediction about people in Indonesia tends to move live in a city that has been done by Tjiptoherijanto (1999). He predicted 55,19\% of people in Indonesia will live in the city than in rural areas in 1995-2020 with annual average urbanization 7,1\%/year [28]. Pulling factors urbanization are opportunity for business or better jobs with better wage, good facilities and services in city ([3]; [14]; [13]; [28]).

In 2018, Indonesia is one of several countries with the highest urbanization level in the world that reach $4,1 \%$. This percentage of urbanization has higher than in China $(3,8 \%)$ and Filipina $(3,4 \%)$ [21]. Moreover, Jakarta is the greatest magnet urbanization in Indonesia which has predicted urbanization level always reach $100 \%$ from 2010-2035 [4]. Similar to prediction, Jakarta has reach 102,89\% of newcomer growth from 68.763 in 2016 to 70.752 in 2017 [26]. 
Lot of newcomer who unskilled and low skilled become difficult to be absorbed in the job market, then they will be absorbed in informal job with low income such as street vendor, parking attendant, construction worker and so on ([6]; [18]; [21]). This is the condition that makes slum areas will growth because many newcomers must survive and find their new house, besides of high cost of transportation that consumes $43 \%$ of their income, house rent/purchase and food [16].

The number of newcomers in Jakarta which is increasing every year is difficult to anticipate by the DKI Jakarta Provincial Government in terms of providing basic needs - especially decent housing for all its citizens. Besides, the limited space in urban areas for settlement land due to the current urbanization indirectly causes the emergence of slum pockets in Jakarta. Some slum areas in Jakarta can be found in several places that are close to the community's economic activities such as in the market. Besides, slum settlements can also be found easily on the edge of a River Basin (DAS) or the edge of a railroad crossing. The process of the emergence of slums is related to newcomers who have low-quality human capital because struggling to survive meets the cost of daily living so that the feasibility of settlements is not a priority for them. In other words, slums are very identical to those who have low-income levels. This is the number of increasing Jakarta's population from 1948's-2016's:

Table.1 Jakarta Population from 1948's to 2016's

\begin{tabular}{cc}
\hline Years & Total Number Population \\
\hline 1948 & 823.356 \\
1949 & 1.349 .625 \\
1961 & 2.973 .053 \\
1971 & 4.684 .000 \\
1985 & 6.164 .848 \\
1990 & 8.200 .000 \\
2000 & 8.400 .000 \\
2010 & 9.600 .000 \\
2015 & 10.280 .000 \\
2016 & 10.300 .000 \\
\hline
\end{tabular}

(Source: Proccesed from [9]; Badan Pusat Statistik, 2017)

If we compare between Jakarta's population in 1948's and 2016's, then 2016's population same as 12 times population from Jakarta in 1948's or same as increasing population in $139.362,41$ people/year for 68 years.

On the other hand, increasing uncontrolled urbanization can trigger conditions of social exclusion - conditions aimed at the weak capacity of the community in various aspects of life. Social exclusion is a process (and also an outcome), individuals or groups separated from broader social relationships - characterized by not participating in community activities such as consumption, saving, production, politics and other social activities [23]. Silver sees social exclusion in three points of view: solidarity; specialization and monopoly. The solidarity paradigm sees the weakening of social ties between individuals in society. The specialization paradigm sees that social exclusion is a consequence of specialization that occurs in society. 
The monopoly paradigm sees exclusion as a result of group monopoly - highlighting the dominance of a group over a particular group [22]. However, the cause of social exclusion in the context of poor communities in slums is not infrequently caused by Government policies. In turn, the existence of poor communities in slums vis-à-vis with spatial planning policies (re: forced evictions). Spatial planning, especially regarding the arrangement of slums in Jakarta, often leads to a form of resident resistance because it refuses to be relocated. The difference in perspective in seeing the concept of slums is one of the causes of miss-communication between the community and policymakers.

Two assumptions explain the emergence of the slum area by UN-Habitat [21]: In general, and traditional slum area categorized as settlement area in the origin which many people want to live there. Because the origin owner of the house moves to a new area or get a better location in the city, they started renting their houses or land for newcomers as additional income. As time goes by which houses live by renting people, then occur degradation of settlement condition then become slum area. In the second, slum areas are emerged by poor or low-income people who built their impermanent houses on unclear land like riverbanks or empty spaces such as under highway, even on government land without or minimum facilities.

Slum area is an environment that is lived mostly by outer/immigrant people which does not fulfill the standard of well-being for human life [21]. The feature of slum area are poor facilities for infrastructure, health, electricity, education, sanitation, poor management for waste, poor accessibility for clean water, rickety house which is lived by more than 3 people, and low safety environment ([4]; [27]).

There are several stigmas for slum area in several aspects. In the physical aspect slum area can be recognized by their house, begin with simple tent become semi-permanent/permanent building with poor amenities for fulfill basic needs ([2]; [21]; [27]). Moreover, slum area tends to appear in government land or green zone such as riverbanks without good governance ([2]; [12]). Usually, slum areas emerge near working place, water facility, and transportation network ([2]; [27]).

Then, slum areas frequently seen or categorized as degradation zone from the city development process in society. Many people live in the slum area tend to have a low level of education [27]. Because slum areas are considered as a source of social problem, social deviation as the nest of criminal, prostitution, alcoholism, and so on ([2]; [11]; [21]) from social aspect.

The economic aspect that describes the slum area is that many people in there have low rate income with a high rate of unemployment. This condition makes them holding their hunger because they have a little money for buying food regularly, moreover thinking about their plan. Politicians frequently using their (slum area residents) as a tool against their political enemy.

Finally, in the environment and health aspect, the slum area has been seen as the source of waste that makes environment degradation and causes many diseases such as scarlet fever ([2]; [17]; [27]).

\subsection{Three Transformation of Slum Settlement}

Hero to Zero: settlements that are not slum then become slums.

Hanggoro explain about hero to zero relate with area not slum become slum in Jakarta from a historical perspective. Same as previous explanation about urbanization, Jakarta always excess of population because its economic attractiveness especially for job that causes of massive infrastructure projects. For welcoming Asian Game in Soekarno's Era around 1960s, Indonesia built a stadium which displace 8.000 house that categorized as "kampong". Jobs opportunity pulled up many people from rural areas and emerged new settlements that were planned or 
unplanned. Several areas as green areas, government land or several placed for public facility changed into crowded settlement like Menteng Atas, Medan Merdeka grass field, Tanah Tinggi, around Gedung Proklamasi, Gajah Mada and Hayam Wuruk Street [11].

In 1960, Jakarta had a deficiency of housing for its people around 1,3 million house that must be provided by the government. Then, Star Weekly Magazine as one of the media which interest in public policy topic saw the "displace" policy as inappropriate action from Jakarta Government. Star Weekly said existing settlement (who is lived by poor people), however, its bad condition to be left standing. Then Soemarno as governor of Jakarta converts the budget for "displace policy" into the budget of infrastructure development [11].

Japanese occupation with scorched earth politics and burning of villages resulted in damaged housing. After World War II, an estimated 2000 homes were damaged. In 1940 1,000 houses were planned, but by the end of 1949, only 20 percent had been realized. To overcome the housing problem, since 1948, a satellite city of Kebayoran Baru has been planned to have an area of 730 hectares. In this area it is projected as a residential area whose edges intersect with the Tanah Abang-Tangerang railroad. Construction began in 1949. Land area of 730 hectares was divided for 152.5 hectares of public housing with a number of 6,730 persil of samadia / moderate housing, 69.8 hectares with 2,198 plots of land, 55.1 hectares of villas with 834 plots of land, 75.2 of special buildings hectares, 6.6 hectares flat, 17 hectares shops, 20.9 hectares industry, 118.4 hectares of city parks, 181.5 hectares of roads and 33 acres of rice fields. All of this is intended to provide a residence for 100,000 residents [9].

The idea of developing the city of Kebayoran originally came from Ir.V.R Vsan Romondt. The idea was on July 19, 1948, discussed at a meeting of the Central Housing Committee. Furthermore, on August 5, 1948, the plan was submitted to the government and on September 21, 1948, the government accepted the plan. To accelerate development, on December 1, 1948 compensation payments to residents had begun. In addition to land, the government also compensated 700,000 trees consisting of 26 kinds of fruit trees, 1,668 houses, stalls, and stables. At this initial stage, on December 1949, the government had issued 15 million guilders [9].

The city development plan was compiled by Practices Ingenieur M. Soesilo from the Central Planologish Bureau. In the plan, the new city to be built is called the Kebayoran Satellite City. The naming of satellite cities is not appropriate because satellite cities are usually located 15 kilometers from the capital, while Kebayoran is only 8 kilometers from the capital. The groundbreaking was carried out on 18 March 1948 [9].

Before being determined as a housing complex ahead of World War II, the Kebayoran area had been researched to become a new international airfield replacing the Kemayoran airfield because it was thought to interfere with the city's expansion to the east, but the plan failed. The implementation of the construction of the new city of Kebayoran was handed over to Central Stiching Wederopbouw (CSW), a foundation established by the government with a notarial deed on June 1, 1948 [9].

Since the transfer of sovereignty in 1950, CSW has changed its name to the Central Rehabilitation Foundation (JPP). Furthermore, based on presidential decree number 65 of 1951 , JPP or CSW was declared dissolved. Property rights and accounts receivable payables are the responsibility of the Indonesian government. To continue development, with the decree of the minister of transportation, public works and personnel on September 4, 1950, a special department was formed, namely the public works department of the new city of Kebayoran starting on June 1, 1950, then in 1952 it was changed again to the Special Development of the New City of Kebayoran, as a organizations within the Ministry of Public Works and Labor [9]. 
The land acquisition for the Kebayoran construction is carried out by the land company, provided that the company pays the state 0.30 guilders per square meter for each persil 2 . Based on these calculations, the government spent Rp. 15 million for land purchases, which included Grogol Udik, Pelapetogokan, North Gandaria, Benajan, Kebayoran Districts, and parts of Jatinegara district. Because it was not enough, in 1951 the funds were added Rp. 2.5 million so the amount was Rp. 17,500,000 [9].

On a land area of 323 hectares, it is planned that 7546 houses will be built, but until 1952 only 4,630 houses have been implemented. The remaining persil that have not been used for public housing 619, samadia / moderate houses 1,344 , villa 459 , and shops 494 , with a total number of uncultivated persil of 2,916 housing developments will be endeavored by providing a broader yard to bring closer relations between residents and nature. According to normal comparisons, the total area of roads, landscaping, and parts is 30 percent of the total city area. In the Kebayoran city plan, this ratio was increased to 50 percent [9].

In early $1951 \mathrm{CSW}$ had completed building 2,058 houses, some of which had been sold, while 1,717 were leased. the cost to build 1,7171 houses is Rp. 19.323.530, and of these there are 788 semi-permanent houses. The house is rented at a between price of Rp. 17.50 and Rp. 100. Besides, in the new city of Kebayoran, 1510 public houses, 183 state class 1 houses, 3 markets, 14 schools, 559 private houses, and 2,015 CSW foundation houses were built. Housing development is not only carried out by the government, but also by government agencies and private companies so that the housing model varies [9].

Based on calculations, the cost incurred for the acquisition of 730 hectares of land is Rp. 16 million-plus Rp. 2.5 million prepare the land to be ready to build Rp. 3.5 million, making primary and secondary roads Rp. 6.25 million, roads Rp. 1.5 million, buildings on the highway Rp. 1.2 million, drinking water Rp. 1.6 million, and waterways Rp. 4.8 million. The total amount is Rp. 38.1 million. This figure does not include investment development costs from electricity and gas companies [9].

Along with the development of the economy in Jakarta which then attracts newcomers to live in the Jakarta area. So, the exception of the Kebayoran Baru Satellite City area is increasingly crowded with residents until the suburbs are gradually becoming slums like in the Kramat Pela village area which is currently included in the Kebayoran Baru Distri3. Based on data from www.kotaku.pu.go.id, the area in Kebayoran Baru Subdistrict included in the Neighborhood Upgrading and Shelter Project (NUSP) program or community-based slum eradication alleviation programs based on recorded community participation in the North Gandaria sub-district with an area of $5.13 \mathrm{Km} 2$, Petogogan Village 5.18 Km2, Kramat Pela 3.91 $\mathrm{Km} 2$. Broadly speaking, not all of the three villages are in the slum category. For example, in the Kramat Pela sub-district that has slums, there are RW 009 on Jalan Pandan and RW 010 in Gang H. Aom (www.Kompas.com).

Zero to Ash: settlements that are slum and end remain up displaced and disappear.

Kampung Pulo located in Jatinegara district, East Jakarta is an area which is located inside of meander Ciliwung River and one of the worst to flooded area when water gate from Bogor opened at heavy rain. On 20 August 2015 in Basuki Tjahya Purnama (a.k.a. Ahok) reign as governor, there is an eviction against some of the dwellers who live at the side of the river. It is said that by law, there should exist a road at the side of the river as an inspection track.

\footnotetext{
${ }^{2}$ Persil is a unit of land size at the time.

${ }^{3}$ The Kebayoran Baru Satellite City Region currently covers the Kebayoran Baru Now Subdistrict area. The Senayan Area is also included in the Kebayoran Baru Subdistrict Area.
} 
If we refer to Hagan's Prism of Crime, there are multi ways to see something as crime, or not. In this Kampung Pulo case, it's a fact that their flooded routine already happened for years without any management from governor. The disaster didn't occur just because there is "water shipment" from Bogor, but also Kampung Pulo side dweller habit to throw garbage in the river. And there is no way to clear the garbage without inspection track. It is true that when Kampung Pulo is flooded, there is help from NGOs and governor, but that is no solution. So, in this way, the governor already commited a crime (an offender) by neglecting his duty resulted in Kampung Pulo get flooded for years.

Which is we could say that when Ahok evicted those who dwell inside of the river, he actually doing his job hence make an inspection track, keep the river clean hence prevent the flood. Of course, there is a resistance from the dweller who got their home evicted. The reason for their resistance is because they had inhabiting that place since 1927, always pay land tax, and some claimed to have certificate as rightful owner of the land and has to be compensated. At first, a negotiation indeed happened between governor, which is Jokowi at that time continued by other representative, and the dweller representative that there will be compensation for those who got evicted. But in Ahok's era, the compensation only for those who have a certificate as a rightful owner. In the end, according to the interviewees, there is no compensation at all, which makes the dweller angry and resist eviction. Which indicated that the Kampung Pulo dweller thinks that they got swindled by governor as their justification. And if the governor tells the truth that compensation only for those who had a certificate, then there is a chance that their certificate is fake or not the right one. In that case, we can say that Kampung Pulo dweller is a victim by someone.

But it's a fact that after eviction there is (almost) no flood at all in the Kampung Pulo, which is according to interviewees kinda make other areas envy them. The Kampung Pulo dweller whose didn't evicted also able to park their vehicle in the inspection track (figure. 3 ). They had to park their car far elsewhere before. Although the area that didn't got evicted is still "slum", hence encourage as a birthplace for a criminal (figure. 4).

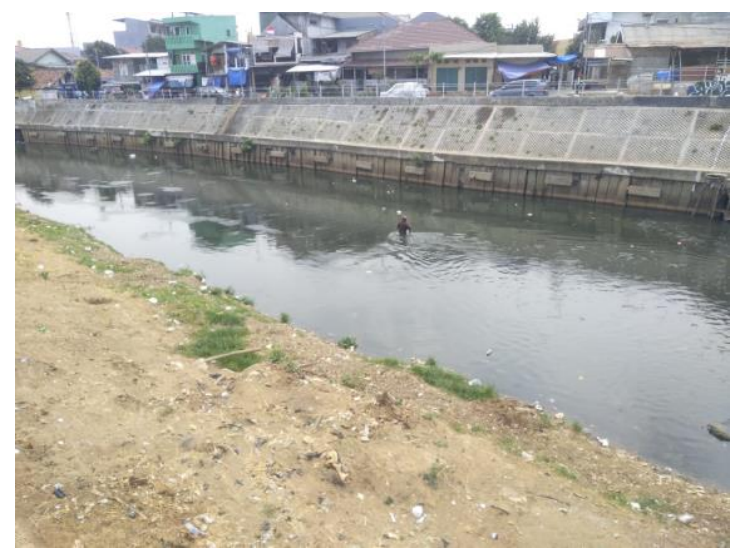

Fig. 2. The Ciliwung River is shallow enough for a person able to stand. (Source: Personal Documentation, 2019) 

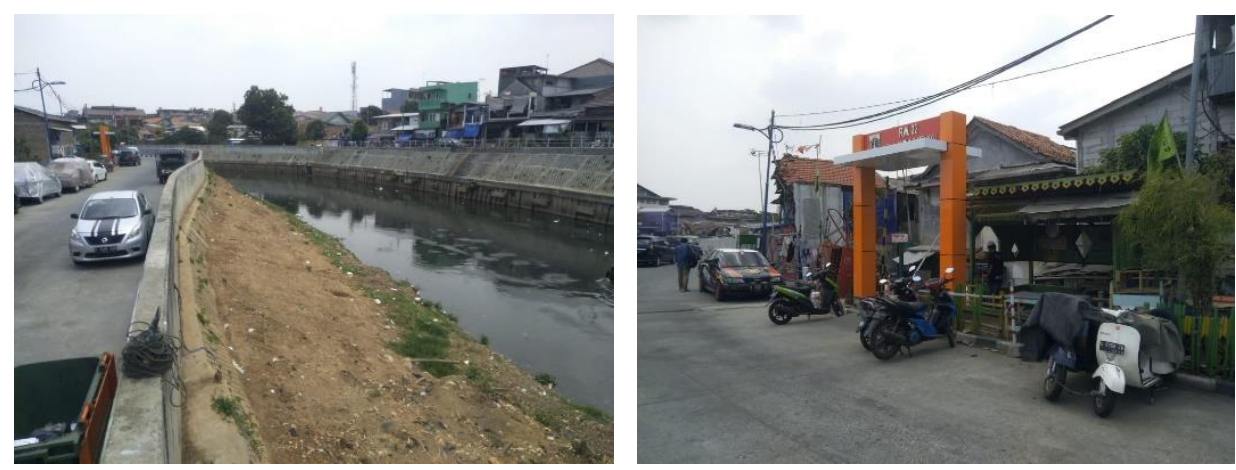

Fig. 3. Inspection Track for Vehicle Park

(Source: Personal Documentation, 2019)

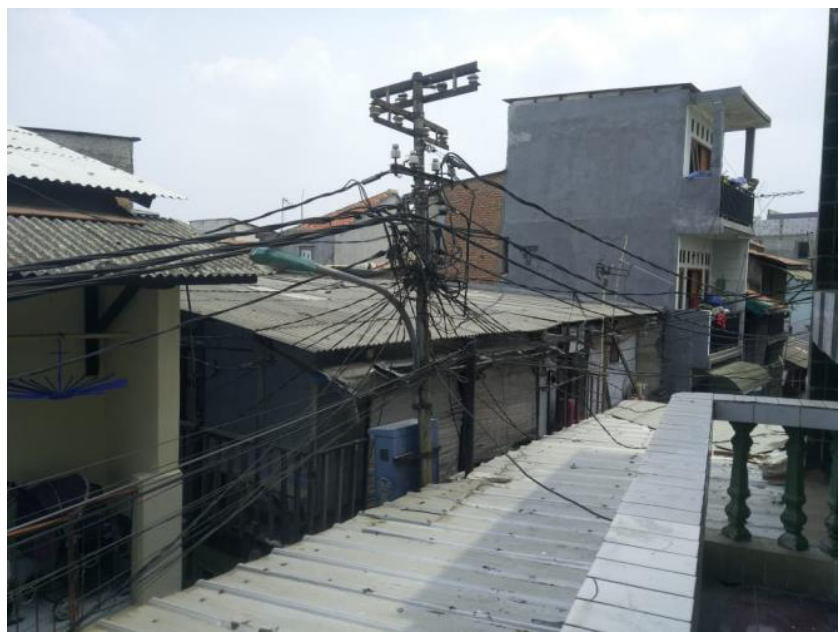

Fig. 4. Still not safety enough, vulnerable when there is fire (Source: Personal Documentation, 2019)

As it said before, that the boy will commit a crime because the "condition" allows him to do it. The objective situation is also important to provide an opportunity for a criminal act. For example, a thief may steal a cake when the owner not in the sight, but will refrain if the owner is in the sight. In Felson \& Cohen's Routine Activity, the cake is the object, the owner is the guardian and the "boy" is the offender. A crime will occur when there is a suitable object, an absence of a capable guardian, and the capable offender. It also means that there is a way to prevent crime by manipulating the environment.

If before the eviction, brawl is tending to happen between area that involved Kampung Pulo and other areas, now it was reduced. And that's because those who used to involved in brawl already move to another place. It's one kind of application of environment manipulation in CPTED.

Zero to Heroes: settlements that are not slum then become slums. 
Assumptions about wild and slum urban villages (Kampung) often lead to the threat of forced evictions. During Governor Basuki Tjahaya Purnama (Ahok), there were at least many cases of evictions during 2015-1016. The reason was because the evicted areas were not intended for settlement, so the settlements that stood there were illegal. Kampung Akuarium, Penjaringan Sub District, North Jakarta became one of the village that found the forced eviction because it was considered as illegal settlements. Kampung Akuarium, is indeed indicated not only as illegal settlements but also slums. Therefore, efforts the resistance of residents ended in vain.

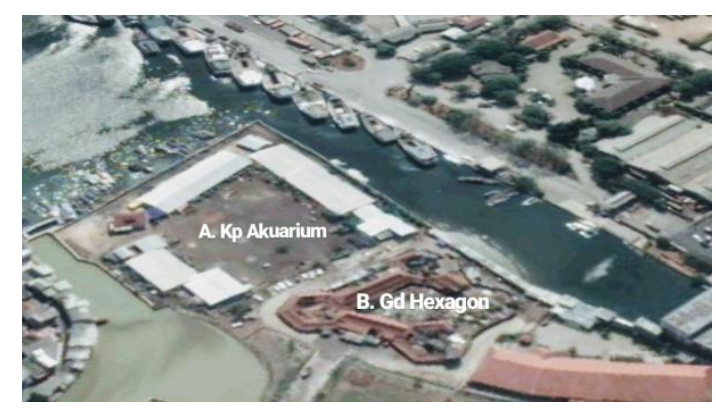

Fig. 5. Location of Kampung Akuarium, Penjaringan Sub District, North Jakarta (Source: Via Google Earth)

The eviction of Kampung Akuarium in 2016 has drawn a lot of protests from the public. Kampung Akuarium is considered as a historical place. In its history, Kampung Akuarium was a witness for the establishment of a marine science research laboratory-Research Center for Oceanography, Indonesian Institute of Sciences (LIPI) since the 1900s ([24]; [20]). In the 1970s, the Research Center was moved to the Ancol District, North Jakarta and Kampung Akuarium area was officially closed for the planned expansion of the Maritime Museum. Then, many residents began arriving and finally settled there-the existence of Kampung Akuarium itself occurred in the process (Interview with Teddy, September 2019). Since the mid-1970s, residents have been living and supporting themselves and their families in Kampung Akuarium, where the sea is their source of livelihood (Interview with Teddy, September 2019).

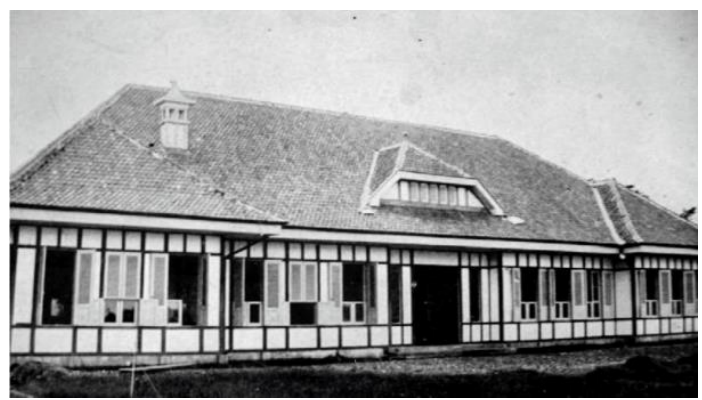

Fig. 6. Batavia Fisheries Laboratory (Visscherij Laboratorium te Batavia) in 1922 (Source: oceanografi.lipi.go.id) 


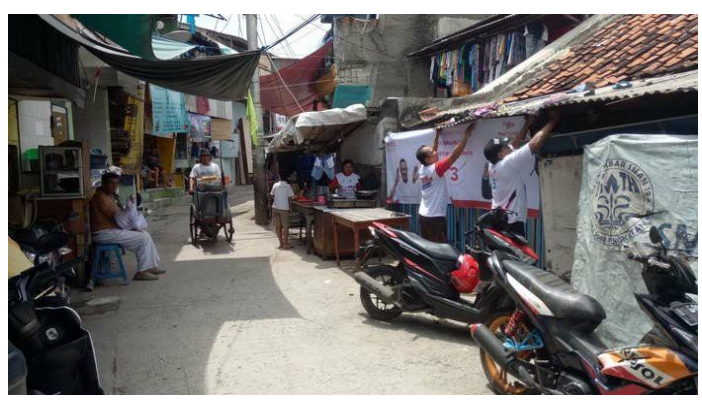

Fig. 7. Kampung Akuarium Before Evicted (Source: wartakota.tribunnews.com)

It cannot be denied, that residents also claim to have certificates that give them the right to occupancy that they have been occupying (Interview with Teddy and Yani, September 2019). Therefore, residents of Kampung Akuarium do not accept if they are considered to inhabit wild areas. Not only that, for residents, Kampung Akuarium is not a slum settlement as the Government considers it (Interview with Teddy, September 2019). Because of that, the people made a resistance the eviction very hard. Even so, the fact is that the physical condition of Kampung Akuarium falls into the slum category if seen at 7 indicators based on the Circular Letter of Ministry of Public Work and Housing (Kementerian PUPR) in 2016 about General Guidelines for Without Slums Program (Program Kota Tanpa Kumuh/KOTAKU). Even though residents resisted strongly, the eviction was inevitable.

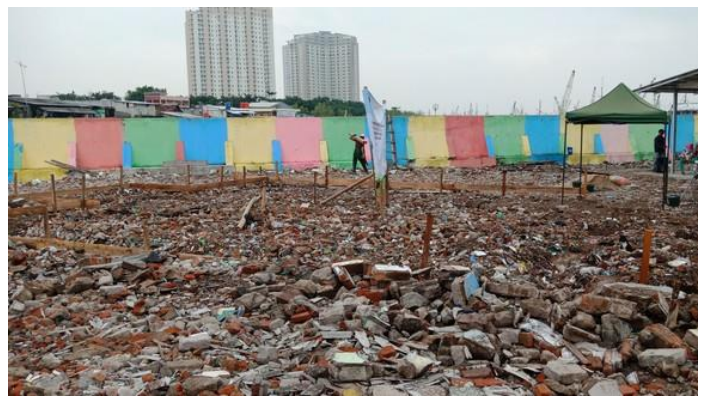

Fig. 8. Kampung Akuarium After Eviction in 2016 (Source: news.detik.com)

After the eviction, residents of Kampung Akuarium continue to carry out advocacy movements and network with NGOs working on related issues, such as the Urban Poor Consortium (UPC), City Poor People's Network (JRMK), and the Rujak Center for Urban Studies after eviction. The climax, these various efforts arrived at the momentum to succeed the 2017 Jakarta Local Election. The residents of the Akuarium Village were accompanied by NGOs as mentioned succeeded in agreeing with Anies Baswedan at that time. The agreement resulted in a political contract in the form of a win-win solution for both parties. Residents and NGOs will give victory at several polling stations for Anies. While Anies will reorganize 16 Kampung in Jakarta that were evicted during the previous Governor's term. In the post-eviction consolidation process, although some residents chose to stay in simple rental flat (Rusunawa), most of them chose to stay in the Kampung Akuarium by inhabiting shelters built by the DKI 
Provincial Government after Anies-Sandi's victory the Jakarta Election in 2017 (Interview with Topas, September 2019).
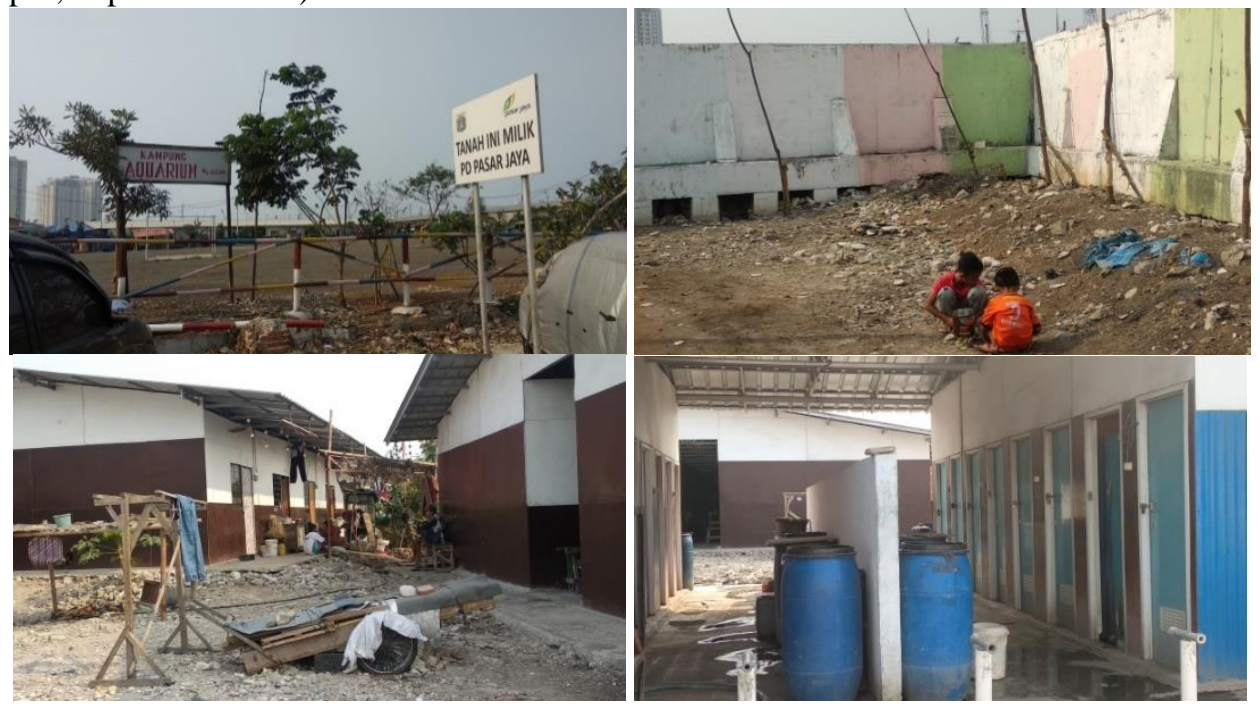

Fig. 9. Kampung Akuarium Today's in 2019

(Source: Personal Documentation, 2019)

The initiative to rebuild the Kampung that was displaced by the political contract was called the Community Action Plan (CAP). For Levitan, CAP is not only a program but a strategy to fight poverty. CAP is a program that means: (1) Mobilizing and utilizing resources, either public or private, or geographical areas in fighting poverty; (2) Providing services, assistance, and other activities to pledge progress towards poverty alleviation; (3) Developed, carried out and managed with maximum participation from the community and group members served; and (4) Conducted, managed, or coordinated by public or private nonprofit institutions (other than political parties), or a combination thereof [15]. CAP is a process that puts the community as a primary source rather than only as an object of development - carried out through mapping, discussion and workshops (UN-HABITAT). CAP is an action plan that places the community as the subject of development. That is, the approach used in the CAP is a bottom-up approach that seeks to explore the problems and potential of the community. Through this approach, the parties involved hope to find ideas and needs that are following the conditions of the community. The CAP emphasizes community involvement in development schemes. Thus, the CAP has inclusive principles because it puts forward a strategy based on the participation, accessibility, and freedom of the community [8].

Under the decision of the Governor of DKI Jakarta No. 878/2018, Kampung Akuarium (RT 012 RW 04) is designated as one of the priority Kampung for implementing the CAP. The implementation of the CAP is divided into two stages, namely the Pre CAP and CAP. The coordinator of the Kampung Akuarium area, Yani and Tedi explained that the Pre CAP stage was an activity of preparation including the formation and training of community work teams, analysis of problems and potentials, tracing the Kampung's history and culture and workshops entitled International Field School in 2018 and 2019. International Field School is a series of training activities in the form of seminars, focus group discussions, and "This is Kampung" 
exhibitions involving residents of the Kampung Akuarium and the Facilitators (UPC, Rujak, JRMK and Academics) in collaboration with Kyoto University.
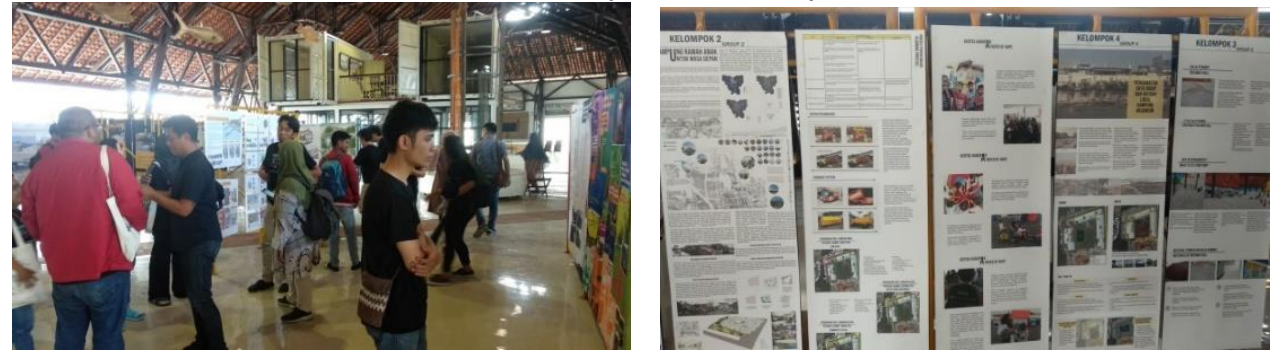

Fig. 10. The "This is Kampung" Exhibition in International Field School at Kampung Akuarium in 2019 (Source: Personal Documentation, 2019)

"This is Kampung" Exhibition, displays the design and concept of the Kampung Akuarium as a result of International Field School activities. Based on its potential and history, the community was accompanied by facilitators to initiate the concept of the Maritime Tourism Kampung which was considered suitable and able to improve the welfare of the community. Through various dialogues and training, the concept of a sustainable Kampung is expected to be ready to start (built) in mid-2020 (Interview with Yani, September 2019). Through CAP, relocation and eviction proved not the only way out for the existence of Kampung which has been negatively imaged by the Government. CAP is thus an attempt to re-arrange according to the needs and expectations of the community-prioritizing to accommodate the rights, ideas and needs of the community rather than depriving the human rights of the poor who inhabit settlements that are considered illegal and slums. The Vertical Kampung Model, initiated by residents and facilitators through the CAP, is considered more humane to guarantee the lives of citizens. The design aims to preserve interaction and culture typical of Kampung and in line with the principles of inclusiveness and sustainability in the development agenda.
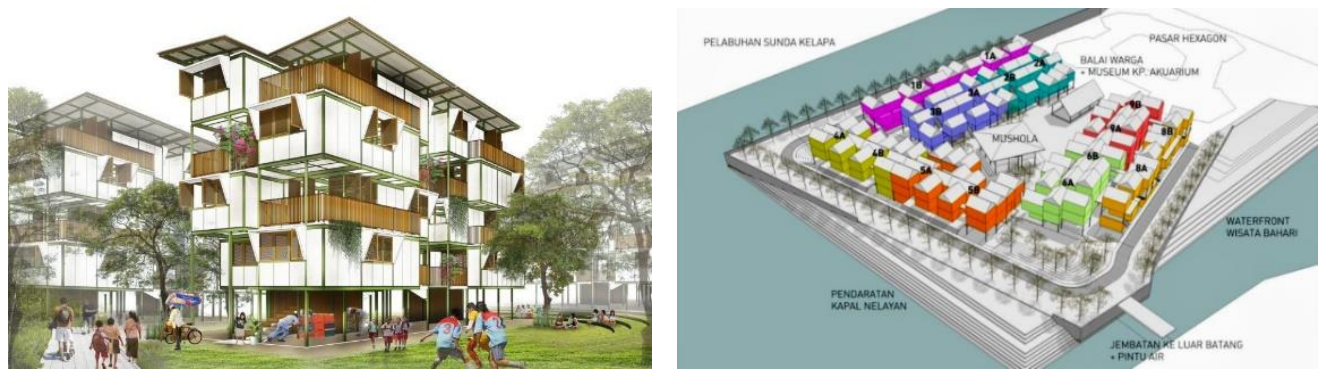

Fig. 11. The Latest Concept of Maritime Tourism Kampung for Kampung Akuarium in September 2019 (Source: Design Andesha Hermintomo and Bardha Gemilang)

Sustainable Inclusive Development: Community Empowerment in Slum Settlements

Community empowerment in improving the quality of the slum settlements means how to improve the community's understanding so that they want to take part in various activities in improving the quality of the environment. Community empowerment efforts by encouraging communities to be independent and can make their own decisions, own initiatives, and improve their lives quality. Involvement or participation can be in the form of contributions of thoughts, 
opinions, and actions, it can also be in the form of costs, materials for improving the environment.

Essentially, empowerment can be seen from its participation in five stages activities, namely activities in taking initiative, planning, implementation, supervision and evaluation, and management and maintenance of the residential environment.

First, the initiative stage. At the retrieval initiatives stage, the community introduced to community empowerment that has a purpose to increase community potential. At this stage, the community is given awareness, encouragement, motivation, opportunities including authority that is following their functions and roles. Furthermore, various problems faced in the settlement environment are introduced, so that from their understanding they can come up with a variety of positive ideas and ideas, because without understanding the problems are usually difficult in bringing up the initiative. What needs to be watched out for in community empowerment are various forms of conflict. This has the potential to occur because in community empowerment it involves various fields such as land, property rights, responsibilities, authority and so on. This potential conflict needs to be avoided.

Second, the planning stage, a community-based approach is very necessary, because basically, not all communities can plan independently. As we know the planning of a residential environment is very complex, including the planning of physical space (spatial) and non-space (a-spatial). Planning physical space in the form of various forms of houses, housing, facilities and infrastructure of the residential environment. Non-space planning in the form of idealism, aspirations, behavioral attitudes from various social, cultural, and economic conditions of the community. Community Action Plan (CAP) is one of the programs in the planning stage.

Third, at the implementation stage of improving the quality of the settlement environment, the community can play a role in various fields, for example in the provision of land, building materials, labor, maintaining order, security and so on. The community can take the opportunity and experience where the community's functions and roles need to be considered, including procedures that must be obeyed to avoid conflicts, because the results are for the community itself.

Fourth, the supervision and evaluation stage. A good supervision system will encourage the acceleration of the implementation of work and the achievement of quality following the plan. At the evaluation stage in the structuring of the environment both at the planning, implementation, and supervision stages there are of course conformity, mismatch, errors and other forms of irregularities. Therefore, all walks of life have an important role.

Fifth, management and maintenance stage. At the stage of management and maintenance of the residential environment is a very urgent thing to do by the members of the community. The success of the management of the residential environment is strongly influenced by the activities of residents who are fostering, building and developing their environment. Various programs that have been implemented well, the community is still expected to carry out management and maintenance of the environment through pure awareness in various forms of participation.

\section{Conclusion}

The dynamics of the slum transition (hero to zero, zero to ash and hero to zero) in Jakarta correlated with the uncontrolled growth of urbanization. In turn, the majority of settlements in Jakarta are inhabited by lower-middle-class people mostly working in the informal economy. 
Some of the slums are identified as illegal areas that are included in the DKI Jakarta Provincial Government's structuring program. The reorganization efforts that led to the relocation immediately increased public dissatisfaction. The stigma attached to slums and squatter settlements and the communication crisis in managing slums are the cause of resistance to enforced evictions. On the other hand, some facts show that there is a tendency of a repetitive process the cycle of change from one condition to another and returns to the original condition. This condition is greatly influenced by the active role of the community and the policies that are put in place.

Therefore, the CAP program implemented in Kampung Akuarium is a breakthrough development paradigm that is more bottom-up. Through that, the principles of accessibility, freedom, and participation are prioritized in managing the village while empowering the community. Through the CAP program, the existence of Kampung Kota in Jakarta will remain sustainable.

\section{References}

[1] Adisasmita, Rahardjo. (2010). Pembangunan Pedesaan dan Perkotaan. Yogyakarta : Graha Ilmu.

[2] Agrawal, V. (2014). Slums: Affects on environment. Recent Research in Science and Technology, 6 (1): 74-77. ISSN: 2076-5061. http://recent-science.com/

[3] Aksi.id. (2019). Gelombang Urbanisasi Jakarta Tekait Kemiskinan dan Kampung Kumuh. 22 Agustus 2019. Accessed from http://aksi.id/artikel/46460/Gelombang-Urbanisasi-JakartaTekait-Kemiskinan-dan-Kampung-Kumuh/

[4] Badan Pusat Statistik. (2013). Proyeksi Penduduk Indonesia. Jakarta: Badan Pusat Statistik.

[5] Badan Pusat Statistik. (2014). Kajian Indikator Sustainable Development Goals (SDGs). Jakarta: Badan Pusat Statistik

[6] Bappenas. (2009). "Kajian Evaluasi Pembangunan Sektoral: Peran Sektor Informal Sebagai Katup Pengaman Masalah Ketenagakerjaan”. Jakarta: Bappenas.

[7] ECOSOC. (2016). Report of the Inter-Agency and Expert Group on Sustainable Development Goal Indicators (IAEG-SDGs): Final List of Proposed Sustainable Development Goal Indicators. Starting point at the 47th session of the UN Statistical Commission held in March 2016 then taken note of by ECOSOC at its 70th session in June 2016.

[8] Fathy, Rusydan., \& Anuraga, Jalu Lintang Y. (2018). Community Action Plan (CAP) dan Kampung Improvement Program (KIP): Studi Komparatif Kebijakan Inklusif Tata Ruang Permukiman di Surabaya dan Jakarta. Proceeding of National Seminar and Urban Sociology Conference: Urban Crisis and Style of Urban Demography. Surakarta: Kekata Publisher.

[9] Gunawan, Restu (2010). Gagalnya Sistem Kanal Pengendalian Banjir Jakarta dari Masa ke Masa. Jakata: Kompas.

[10] Hanggoro, H. T. (2019). Dari Dalam Kampung Kumuh Ibukota. Hostoria. Accessed from https://historia.id/urban/articles/dari-dalam-Kampung-kumuh-ibukota-DwgXl

[11] Hanggoro, H. T. (2011). Masalah Permukiman di Kota: Sejarah Permukiman Kumuh di Jakarta 1960-1969. Depok: University of Indonesia.

[12] Haq, M. F.U. (2019). "Kementerian ATR Sebut Hampir 49 Persen Permukiman di DKI Kumuh". Detiknews. 27 mei 2019. Accessed from https://news.detik.com/berita/d4566878/kementerian-atr-sebut-hampir-49-persen-permukiman-di-dki-kumuh

[13] Hussain, T., Abbas, J. Wei, Z., and Nurunnabi, M. (2019). The Effect of Sustainable Urban Planning and Slum Disamenity on the Value of Neighboring Residential Property: Application of the Hedonic Pricing Model in Rent Price Apprisal. Sustainability, 11, 1144; DOI: $10.3390 /$ sus 11041144 .

[14] Joga, N. (2019). Urbanisasi dan Keberlanjutan Kota. Tempo.co. 8 Januari 2019. Accessed from https://kolom.tempo.co/read/1162550/urbanisasi-dan-keberlanjutankota/full\&view=ok 
[15] Levitan, Sar. A. (1969). "The Community Action Program: A Strategy to Fight Poverty". Diunduh dari http://journals.sagepub.com/doi/abs/10.1177/000271626938500107.

[16] Media Indonesia. (2019). Kemiskinan Picu Kemunculan Kampung Kumuh. 31 Januari 2019. Accessed from https://www.medcom.id/nasional/metro/zNAL1JZK-kemiskinan-picukemunculan-Kampung-kumuh.

[17] Moosavi, M. (2011). An Introduction to Environmental Challenges of Life in Slum Settlements of Tabriz. 2nd International Conference on Humanities, Historical and Social Sciences. IPEDR Vol. 17. IACSIT Press, Singapore

[18] Noveria, M. (2008). Mobilitas Penduduk Musiman di Kota Surabaya: Dampaknya Terhadap Lingkungan Permukiman Kumuh. Jurnal Kependudukan Indonesia, III (1): 2008: 37-50.

[19] Okafor, B., N., and Onuoha, D. C. (2016). The Effect if Slum on Property Values in Asaba Metropolis of Delta State. British Journal of Environment Science, 4(3): 17-33. Publisher: European Centre for Research Training and Development UK (www.eajournals.org)

[20] Pariwono, J. I., A. G. Ilahude and M. Hutomo. (2005). "Progress in Oceanography of The Indonesian Seas" A Historical Perspective". Oceanography, Vol 18 (4): 42-49.

[21] Prabowo, Dani. (2018). "Laju Urbanisasi Indonesia Tertinggi di Asia". Kompas.com. 4 Juli 2018. Accessed from https://properti.kompas.com/read/2018/07/04/210000321/lajuurbanisasi-indonesia-tertinggi-di-asia.

[22] Silver, Hillary. (1994). "Social Exclusion and Social Solidarity: Three Paradigm". International Labour Review, Vol 133: 531-578.

[23] Sirovatka, Thomas and Petr Mares. (2008). "Social Exclusion and Forms of Social Capital". Czech Sociological Review, Vol 44 (3): 531555.

[24] Soegiarto K. (1987). "Menelusuri Tonggak-Tonggak Sejarah Puslitbang Oseanologi LIPI". Oseana, Vol 12 (3): 1-52.

[25] Sutherland, E. H., \& Cressey, D. R. (1960). Principles of criminology. Chicago: Lippincott.

[26] Syadzilly, Ace Hasan. (2017). "Urbanisasi dan Kesenjangan Kota-Desa". News.com. 20 Juli 2017. Accessed from https://nasional.sindonews.com/read/1222235/18/urbanisasi-dankesenjangan-kota-desa-1500479252

[27] Tanni, T.T., Hasan, M. J., Azad, A.K., and Bakali, B. (2014). State of the Environment in Slum Area: A Case Study on Khora Slum, Khulna. ISSN 1999-7361. Journal Environmental Science \& Natural Resources, 7 (1): 295-304.

[28] Tjiptoherijanto, P. (1999). Urbanisasi dan Pengembangan Kota di Indonesia. Populasi, 10 (2):57-72. Accessed From https://journal.ugm.ac.id/populasi/article/download/12484/9035

[29] Wijaya, L. D. (2019). "BPN Sebut 49 Persen Wilayah DKI Jakarta Masuk Kategori Kumuh". Tempo.co. 27 Mei 2019. Accessed from https://metro.tempo.co/read/1209870/bpn-sebut-49persen-wilayah-dki-jakarta-masuk-kategori-kumuh/full\&view=ok. 